\title{
Non-invasive care technologies: nurses' contributions to the demedicalization of health care in a high-risk maternity hospital
}

Tecnologias não invasivas de cuidado: contribuições das enfermeiras para a desmedicalização do cuidado na maternidade de alto risco

\section{Tecnologías no invasivas de cuidado: contribuciones de las enfermeras para la desmedicalización del cuidado en la maternidad de alto riesgo}

\author{
Juliana Amaral Prata ${ }^{1}$ (D) \\ Lana Priscila Meneses Ares $^{1}$ (C) \\ Octávio Muniz da Costa Vargens ${ }^{1}$ (1] \\ Carlos Sérgio Corrêia dos Reis ${ }^{1}$ \\ Adriana Lenho de Figueiredo Pereira ${ }^{1}$ (C) \\ Jane Márcia Progianti ${ }^{1}$ (i)
}

1. Universidade do Estado do Rio de Janeiro.

Rio de Janeiro, RJ, Brasil.
Corresponding Author:

Juliana Amaral Prata.

E-mail: juaprata@gmail.com.

Submitted on $10 / 11 / 2018$.

Accepted on 01/22/2019.

DOI: 10.1590/2177-9465-EAN-2018-0259

\begin{abstract}
Objective: to discuss the use of non-invasive care technologies by nurse-midwives in a high-risk maternity hospital. Method: a descriptive and qualitative study with ten nurse-midwives who work at the obstetric center of a high-risk maternity at a university hospital in Rio de Janeiro City. Data collection took place in June and July 2017, through a semi-structured interview. The material was submitted to content analysis. Results: The participants use non-invasive care technologies from the perspective of health work technologies and demedicalization, setting up a care process centered on sensitive work and soft technologies. Thus, they shift the focus away from interventionist procedures and develop a care based on human relationships, integrality and female protagonism. Conclusion: with these technologies, nurse-midwives perform a new way of caring in high-risk maternity hospitals, contributing to the humanization of care and rearrangement of these fields. Implications for the practice: the use of these technologies drives the change of the care model by focusing on sensitive work and soft technologies instead of rough work and procedural hegemony.
\end{abstract}

Keywords: Nurse-midwifery; Technology; Women; Humanization of care.

\section{Resumo}

Objetivo: Discutir o uso das tecnologias não invasivas de cuidado por enfermeiras obstétricas em uma maternidade de alto risco. Método: Estudo descritivo e qualitativo, com dez enfermeiras obstétricas que atuam no centro obstétrico de uma maternidade de alto risco de um hospital universitário do Rio de Janeiro. A coleta dos dados aconteceu em junho e julho de 2017, através de entrevista semiestruturada. O material foi submetido à análise de conteúdo. Resultados: As participantes utilizam as tecnologias não invasivas de cuidado sob a ótica das tecnologias do trabalho em saúde e na perspectiva da desmedicalização, configurando um processo de cuidar centrado no trabalho vivo e nas tecnologias leves. Desse modo, retiram do foco os procedimentos intervencionistas e desenvolvem um cuidado pautado na relação humana, na integralidade e no protagonismo feminino. Conclusão: Com essas tecnologias, as enfermeiras obstétricas introduzem um novo modo de produzir o cuidado nas maternidades de alto risco, contribuindo para a humanização da assistência e reconfiguração desses campos. Implicações para a prática: $O$ uso dessas tecnologias impulsiona a mudança do modelo assistencial, a partir do enfoque no trabalho vivo e nas tecnologias leves em detrimento ao trabalho morto e à hegemonia centrada em procedimentos.

Palavras-chave: Enfermagem obstétrica; Tecnologia; Mulher; Humanização da assistência.

\section{Resumen}

Objetivo: discutir el uso de las tecnologías no invasivas de cuidado por enfermeras obstétricas en una maternidad de alto riesgo. Método: estudio descriptivo y cualitativo, con diez enfermeras obstétricas que actúan en el centro obstétrico de una maternidad de alto riesgo de un hospital universitario de Rio de Janeiro. La recolección de los datos ocurrió en junio y julio de 2017, a través de una entrevista semiestructurada. El material fue sometido al análisis de contenido. Resultados: las participantes comprenden las tecnologías no invasivas de cuidado bajo la óptica de las tecnologías del trabajo en salud y las utilizan en la perspectiva de la desmedicalización, conformando un proceso de cuidar con énfasis en el trabajo vivo y en las tecnologías blandas. Así, desplazan el foco de la intervención y desarrollan un cuidado pautado en la relación humana, en la integralidad y en el protagonismo femenino. Conclusión: con estas tecnologías, las enfermeras obstétricas introducen un nuevo modo de producir el cuidado en las maternidades de alto riesgo, contribuyendo para la humanización de la asistencia y reconfiguración de esos campos. Implicaciones para la práctica: el uso de estas tecnologías impulsa el cambio del modelo de asistencial a partir del enfoque en el trabajo vivo y en las tecnologías blandas en detrimento del trabajo muerto y la hegemonía centrada en procedimientos.

Palabras clave: Enfermería obstétrica; Tecnología; Mujeres; Humanización de la atencíon. 


\section{INTRODUCTION}

Throughout the 1990s, in a world context favorable to women's discussions, critics about the model of obstetric care in force emerged, characterized by the excessive use of interventions on women and the medicalization of childbirth. These issues, coupled with the high rates of maternal and neonatal mortality, led to the organization of a network of movements for the humanization of childbirth and birth, which fought for the autonomy of women through the rescue of vaginal birth with the minimum of interventions possible. ${ }^{1}$

In Brazil, these demands gained visibility within public policies, and humanization was incorporated into the programmatic discourses of the Unified Health System (SUS), with the elaboration of documents highlighting the recovery of women's protagonism and the appropriate use of technologies in obstetric care. Seen that, obstetrics nurses played an essential role in the implementation of humanized practices in health services; they showed specific skills to value the feminine during parturition, understanding it as a unique physiological event that permeates the different contexts of women's lives. . $^{2,3}$

Since then, these specialists have been standing out in the consolidation of the humanized model, mainly through the demedicalization of care to women as the guiding axis of the care process of obstetrics nurses, which generates nonmedical practices that respect the feminine physiology and value the autonomy of women. ${ }^{4,5}$

From this perspective, non-invasive obstetric nursing care technologies (Tecnologias Não Invasivas de Cuidado de Enfermagem Obstétrica - TNICEO) are fundamental, since they consist of knowledge structured, developed and used by obstetric nurses, to offer other possibilities for women to experience birth and delivery. Thus, they involve attitude changes in the relationship with women, in which professionals play a supporting role and conceive care as a shared construction that promotes women's empowerment. ${ }^{2,5,6}$

Based on these conceptions and considering that the use of TNICEO in care for low-risk women is related to safe, quality obstetric care and with widely favorable maternal and neonatal outcomes compared to the practices of the medicalized mode ${ }^{17-14}$, the use of these technologies must be considered in the context of obstetric risk situations. Although they are considered as impeding the direct performance of obstetrics nurses in childbirth care, these specialists are responsible for the integral care of women during their stay in obstetrical centers, regardless of the risk classification and the care profile of the institution.

Considering the above, this study aimed to discuss the use of non-invasive obstetric nursing care technologies by obstetrics nurses in a high-risk maternity. Research became relevant since there is a gap in the scientific literature about the performance of obstetrics nurses in the care of women with associated obstetric risk, prevailing the approach of TNICEO in situations of low risk.

\section{METHODS}

This is a descriptive and qualitative study, carried out with ten obstetrics nurses, who work in the obstetrical center of a high-risk maternity hospital, linked to a university hospital in the state of Rio de Janeiro.

The inclusion criterion was professionals who had been working with care during parturition for more than six months. The exclusion criteria were specialists who were absent during the period of data collection. Finally, of the eleven obstetrics nurses who work in the institution, only one did not participate in research because she was on medical leave.

Data collection took place in June and July 2017, through a semi-structured interview, following a script with the following open questions: What do you mean by non-invasive obstetric nursing care technologies? Do you use these technologies in obstetric care? Which of these technologies do you use and why?

Searching participants began with a previous contact, for a brief explanation of research, followed by the invitation to participate. After the acceptance, a meeting was arranged to conduct the interview, in a privacy-ensured environment. With proper authorization, the interviews were individually recorded in digital audio files and later transcribed and transcreated.

The material obtained in the interviews was submitted to content analysis ${ }^{14}$ and involved the following stages: pre-analysis, which consisted in systematizing the ideas that emerged from the interviews; followed by floating reading; exploration and organization of the material, which defined the registration units; and coding, which identified the units of meanings and grouped them into larger sets, according to the common characteristics of their elements.

In compliance with Resolution No. 466/201215, the participants signed a Free and Informed Consent Term, declaring their voluntary participation and the maintenance of anonymity. For this purpose, the letter I was adopted, concerning the term interviewed, followed by a number, representing the order of interviewing.

The project was approved by the Research Ethics Committee of the State University of Rio de Janeiro (Universidade do Estado do Rio de Janeiro), under Opinion No. 2.171.248 and CAAE No. 64217016.7.3001.5259, dated May 2017.

\section{RESULTS}

Two categories resulted from the analytical process of interviews: Using TNICEO under the perspective of health work technologies; and Using TNICEO under the perspective of demedicalization.

\section{Using TNICEO under the perspective of health work technologies}

This category evidenced that, from the perspective of health work technologies, TNICEO are relational attitudes, knowledge, 
objects and procedures that nurses use to care for high-risk parturients:

It's theoretical knowledge! We must know the physiology of childbirth! We must know how birth... You must use the technologies you have available: if there's a ball in the unit, objects for pelvic exercise, a massager, an aroma... Sometimes there is nothing of this, but only because you're giving psychological support and guidance it helps... So, the nurse will use theories and the physical technologies available in the unit and give psychological support! (I 02).

We use methods, objects, and even words so that we can work with the woman. To offer this woman what she needs so that she understands what is being done, why we are using this or that, to facilitate labor, minimize the pain... They need support because they are already under a heavy emotional load! They already have some pathology! [...] Here, we have a ball, objects for pelvic exercises, a shower... I try to offer, in a subtle way, bathing, walking, breathing and dimming the lights. (I 05).

It involves welcoming, listening, looking with attention for the woman and the family. [...] there are things that will not involve any objects, like a massage you can do even without oil, just using your hands! A dark, warm environment, conscious breathing... Things we can do to guide women to better go through this process. (I 07).

In this perspective, the initiatives taken emerged as the most expressive TNICEO in the speeches of obstetrics nurses:

Midwifing demands time, your availability to be there with the patient, evaluate, observe... Giving means you're there with her, showing how it works, evaluating and keeping up. [...] clarifying doubts is very important and this is also caring because the attention must be valued along with the needs of the patient. (I 01).

The lighting, the calm of the environment, the availability of the professional, the delivery... The fact that professionals were there, concentrated at that moment, directing the energy for that patient. (I 03).

Offering comfort for that patient! She will need support, host... Any woman can have this support, this host, regardless of whether she is high risk or low risk. (I 04).

Respecting the singularities of each woman and under a sensitive follow-up, they understand that TNICEO may also involve offering some objects to parturients with associated obstetric risk:
[...] The radio playing a song to create a better environment, where she can relax through music, the use of essences, a warm bath, objects, a ball... You must keep up! Be together! (I 01).

They involve the ball, the objects, a warm bath, the walking. The patient chooses the position she feels best and let her, under a supervised look, direct her labor and delivery! (I 06).

Then there are some objects we can use in these technologies, such as: a ball, objects for pelvic exercises, a stool, a shower, a bathtub, massagers, aromas... (I 07).

In addition, participants stated that the use of TNICEO encompasses theoretical and technical knowledge, scientific evidence and practical experience.

It is about knowing what each of these objects is for, what is the purpose of each one, at which point they can be used... You also must know the dynamics of labor, its phases, know exactly at what moment you can apply each technology! [...] You must understand, at each stage, what is most appropriate to apply at that moment and understand the moment when the woman needs silence, resting and storing energies for the active labor. (I 03).

People who came before us conducted studies and developed the whole theoretical basis of these technologies we use today. So, we can also study this in theory, and it is already described in the city's obstetric nursing manual, in scientific articles... I also think that there is knowledge that comes from your practice! (I 06).

\section{Using TNICEO under the perspective of demedica- lization}

This category showed that TNICEO are used in the perspective of demedicalization because in the process of caring for high-risk parturients, there is an intention to respect the female physiology and experiences, not invade the body, encourage active participation and promote women's empowerment.

A set of techniques, procedures and knowledge that obstetrics nurses use during the care between the professional and the parturient, aiming to make the delivery as physiological as possible, respecting the woman's nature, culture, her psychic and all her desires during childbirth. Therefore, nothing impedes us from giving full support to high-risk women, even if delivery does not happen with our assistance there, but it's necessary and it makes all the difference! This woman, even if we are only offering 
our support, when she is going to give birth, even if it is with another professional, she will feel much safer! (I 02).

\begin{abstract}
Sometimes people think that because we work with high risk, women do not need them [the TNICEO]. I think women are those who need TNICEO the most! There is always something that can be done within the woman's clinical conditions! You can massage, offer to dim the lights, provide an aroma, a bath... It all reduces labor time and pain, facilitate movements and I think they get more focused. They empower themselves in what they're living! (I 06).
\end{abstract}

I think these [the TNICEO] within high risk situations also bring benefits because if anxiety and painful perception are decreased, you improve the specific clinical picture of some pathologies. You trigger the pregnant woman's natural understanding for acceptance, availability, and involvement. They help you to use mechanisms that do not interfere with mechanics or body functioning, so you do not invade their organic components! Let it be a natural mechanism and let them participate of it! (I 08).

\section{DISCUSSION}

The results of the analytical process showed that the use of relational skills, the promotion of a welcoming environment, the encouragement of active participation of women and of walking were presented as the TNICEO most used by obstetrics nurses of this study in the care of women with obstetric risk associated. Professionals also use instruments such as balls, objects for pelvic exercises, warm water, aromas, and procedures like massages, aimed to develop a caring process whose main purposes are to offer emotional support, encourage women's empowerment, favor parturition, alleviate tension and promote comfort.

From this perspective, participants understand that relational attitudes, body postures, knowledge and objects are integral elements of TNICEO. This perception refers to the definition of technology applied to health work, which comprises a set of elements used by professionals during the promotion of care, passing through material and immaterial resources that acquire meaning and are applied in a unique way according to the worldview that guides their care process. ${ }^{16}$

Health technologies are classified as: hard technologies, represented by instruments, equipment, permanent machines, physical installation, norms and organizational structures; soft-hard technologies with structured knowledge and knowledges; and soft technologies, shown in human relationships, relational processes, communications and in the way of managing care and services. ${ }^{17-22}$

In this sense, it was found that in the care of high-risk parturients, the obstetric nurses in the study predominantly use soft technologies ${ }^{2,4-6,23}$. The participants highlighted the following
TNICEO as the most used: emotional support, guidance and clarification of doubts; appreciation for the needs of women; sensitive and continuous monitoring; availability, acceptance and empathy; women's freedom of choice; qualified listening, a different look and an appropriate touch; welcoming and privacy environments; conscious breathing and walking; respect for the role of women; encouragement of the participation of companions; promotion of comfort and relaxation; and encouragement of women's empowerment.

Soft technologies consist of relational-based knowledge that is used when professional and user meet, for the purposes of reception, bonding, communication and autonomy. The predominant use of these technologies is consistent with care modes founded on a humanized care model, which is based on sensitive work. ${ }^{16,24,25}$

In the perspective of nursing, these technologies are configured as attributes of the human relationship that integrate care, situated in the subjective dimension of care that translates into behaviors, attitudes and postures manifested during the nurse's encounter with the client. In this interactional space, relational skills are fundamental for the shared construction of therapeutic care concerned with women's autonomy and empowerment. ${ }^{25,26}$

This process involves different forms of interaction, which favor bonding, externalizing feelings, and recognizing subjectivities and the real needs of patients, in which dialogue is the integrating axis of care. Therefore, to establish a relationship of trust and help, some skills inherent to the nurse's know-how are necessary, such as: considering the influence of socio-cultural aspects and the environment for clients' comfort and well-being; using verbal and non-verbal communication to express sensitivity, reciprocity, affection, interest, and acceptance; understanding and respecting the meanings attributed to each person's experiences; demonstrating body language of solidarity and involvement; valuing the concerns and questions; and promoting the exchange of information and knowledge. ${ }^{24,25,27,28}$

On the other hand, hard technologies also emerged as integral elements of the TNICEO, present in the participants' speeches as playing songs in radio for ambient music, aromas, immersion and aspersions bath, objects for pelvic exercises, the Swiss ball, massagers and stools. As artificially manufactured material resources that are used by obstetrics nurses in the care process, these artifacts represent hard health work technologies or product technologies. ${ }^{19,29}$

This type of technology, expressed in durable goods that act and intervene in the objectivity and subjectivity of human beings, brings certain materiality and impersonality, which can be overcome by understanding that it is the care that, through nurses, uses equipment. ${ }^{19}$ Considering that, hard technologies mediate thinking and action, and are subsidized by knowledge and professional experience, while its use permeates the reflection about the relational and humanistic nature of care production. ${ }^{18,21}$

In addition to attitudes, postures and objects, all participants emphasized that TNICEO also encompass theoretical and tech- 
nical knowledge, scientific evidence and knowledge emanating from practice. This framework can be glimpsed in the perspective of healthcare technologies used in health work as soft-hard technologies, defined as immaterial resources involving a hard sphere, represented by structured knowledge and standardized knowledge, and a soft one, referring to the singular mode how these factors are applied to produce care..$^{29}$

In Nursing, the hard part of these technologies forms a more organized know-how from the nursing process and the knowledges expressed in the official manuals and recommendations. On the other hand, the soft part covers the theoretical and technical knowledge of Health, Nursing and Obstetric Nursing specialty, nursing theories and fundamentals, as well as care models. 18,19,30

Scientific evidence, skills and knowledge from practice are also in this category, which were cited by obstetrics nurses in the study and are consistent with other soft-hard technologies. This knowledge is produced in everyday experience and research from perceived needs in the real context of professional practice. ${ }^{20,21}$

Additionally, the specialized knowledge required to use equipment in care, such as its indications, applicability and handling, must be considered. They are considered soft-hard technologies that scientifically substantiate the use of hard technologies, through the mediation of relational processes characteristic of soft technologies. ${ }^{16}$

Thus, from the results of the first category, it was found that the participants of the study use TNICEO as a set of elements, which, according to Merhy ${ }^{17}$, can be apprehended: as soft technologies, in the case of relational attitudes and body postures; as soft-hard technologies, corresponding to knowledge; and as hard technologies, represented in objects and procedures.

Considering that soft technologies were the most expressive in the speeches, the process of caring by these obstetrics nurses in high-risk maternity, with the use of TNICEO, presents a focus on sensitive work, given the predominance of a type of technology in the health work process points to a certain care model so that the production of care can be organized around: dead work, when it is based on a prescriptive and procedural model, centered on biomedical knowledge and with the use of hard technologies; or sensitive work, which consists of a relational model based on when workers meet patients and their subjectivities, which integrates different knowledges with the use of soft technologies for a humanized and integral care, with the valorization and promotion of autonomy. ${ }^{16}$

This finding is in line with what is expected for professional performance in the high-risk obstetrics, where it is common to see the predominance of dead work and the use of hard technologies. ${ }^{31-33}$ This contradiction seems to be the result from the principles that guide the study participants in the use of TNICEO, since the world view that supports the construction of care determines the meanings that are attributed to the resources involved in this process, which can be apprehended in the perspective of sensitive or rough work. ${ }^{28,29}$

Considering that the use of TNICEO in the process of caring for high-risk parturients is aimed at respecting women's phy- siology and experiences, not invading the body, encouraging active participation and promoting women's empowerment, it is perceived that obstetric nurses in this study develop care with unmedicalized characteristics.

The conception of demedicalization of women's care involves changes in the attitude of professionals in their interaction with women. It can occur by eliminating the clinical-biomedical reasoning as the only alternative for obstetric care, incorporating new perspectives and knowledge about childbirth and admitting the possibility of offering other options for women to experience parturition and birth, with the use of TNICEO. ${ }^{4,5}$

To achieve that professionals must understand that women are the protagonists of their birth, a biological event influenced by their existential context, demanding care and not control; nursing care incorporates, here, intuition as opposed to the use of practices that stimulate rationality; nurses respect women's privacy and safety realizing that any procedure that invades their body requires clarification and prior authorization. ${ }^{4,5}$

These principles of demedicalization were identified in the participants' speeches, since the use of TNICEO converges to the construction of a sensitive care, based on the human relationship and shared decision, integrality, autonomy and respect for women's rights. ${ }^{2,4-6,23}$

In the condition of scientific, clinical and obstetric knowledge mediated by unmedicalized attitudes, the use of these technologies favors the physiological development of parturition and birth, reduces pain and the need for interventions. On the other hand, it also facilitates trust-based bonding, promotes comfort, encourages the participation of companions, reduces anxiety, relieves tension and encourages active participation of women, providing a pleasurable experience of giving birth and being born. ${ }^{4-6,23}$

From the perspective of safety and health quality, scientific evidence confirms that using TNICEO is associated with a positive experience of parturition and birth, and presents favorable maternal and fetal outcomes, such as: facilitating the release of endogenous oxytocin; allowing light movement and enlargement of the pelvis diameter, helping the baby to come out and fetal rotation through the birth canal; favoring dilation of the uterine cervix; minimizing pain, from the release of catecholamines and the elevation of endorphins; facilitating the progression of the active phase; improving blood flow and oxygenation of tissues; promoting relaxation; and reducing anxiety, stress and fear. ${ }^{7,9,12,34-38}$

Seen that, it was observed that obstetrics nurses in this study develop a care process with demedicalized characteristics and focus on sensitive work, from the use of TNICEO, especially those classified as soft. Thus, parturients and their subjectivities are placed in the centrality of high-risk maternity care, where, commonly, the valorization of biomedical pathology and knowledge forms a prescriptive and interventionist logic about parturition, focusing on rough work and hard technologies.

In this sense, the innovative character of TNICEO and their potential to reset high-risk Obstetrics is seen. With them, obstetrics nurses introduce a new way of providing care based on soft technologies and sensitive work. 
This inference refers to Merhy's concept ${ }^{17,39}$ on productive restructuring in health, understood as technological incorporations or changes in the organization of work that add new meanings to health care. These changes can redefine how professionals act, and consequently, modify the care model, with the prioritization of sensitive work in detriment to the hegemony centered in procedures.

\section{CONCLUSIONS AND IMPLICATIONS FOR PRACTICE}

This study showed that, in the process of caring for high risk parturients, obstetrics nurses use TNICEO from the perspective of health work technologies and from the perspective of demedicalization of care for women. Thus, they are transforming agents of the logic of providing care in high risk obstetric fields because they place women at the center of care and predominantly use soft technologies.

Based on this observation, the importance of investing in the Brazilian Obstetrical Nursing practice is highlighted and is not limited to low-risk situations, giving that the use of TNICEO in high-risk maternity is a technological innovation with great potential to boost the exercise of citizenship of women, the humanization of care and, above all, the change of the model of obstetric care from the focus on sensitive work and soft technologies to the detriment of rough work and the hegemony centered on procedures and interventions.

As research limitation that prevents generalizations, it is a local study carried out in a single high-risk maternity, thus pointing to the need for further investigation in these care settings. Nonetheless, the findings are valid because they reflect similar results found in more extensive studies in low obstetric care units, where the use of TNICEO and the demedicalized care process are contributing to the effectiveness of public health policies for women and granting autonomy to Nursing in the context of the humanization of childbirth and birth.

\section{REFERENCES}

1. Tornquist CS. Parto e poder: o movimento pela humanização do parto no Brasil [doutorado]. Florianópolis (SC): Universidade Federal de Santa Catarina; 2004.

2. Vargens OMC, Silva ACV, Progianti JM. Contribuições de enfermeiras obstétricas para consolidação do parto humanizado em maternidades no Rio de Janeiro. Esc Anna Nery [Internet]. 2017; [cited 2018 Apr 10]; 21(10):e20170015. Available from: http://www.scielo.br/pdf/ean/ v21n1/1414-8145-ean-21-01-e20170015.pdf. DOI: http://dx.doi. org/10.5935/1414-8145.20170015

3. Prata JA, Progianti JM, David HSL. A reestruturação produtiva na área da saúde e da enfermagem obstétrica. Texto Contexto Enferm [Internet] 2014 Oct/Dec; [cited 2017 Oct 28]; 23(4):1123-9. Available from: http:// www.scielo.br/pdf/tce/v23n4/pt_0104-0707-tce-23-04-01123.pdf.DOI: http://dx.doi.org/10.1590/0104-07072014002040013

4. Progianti JM, Vargens OMC. As enfermeiras obstétricas frente ao uso de tecnologias não invasivas de cuidado como estratégias na desmedicalização do parto. Esc Anna Nery [Internet]. 2004 Aug; [cited 2017 Jun 9]; 8(2):194-7. Available from: http://www.redalyc.org/articulo. oa?id=127717713004
5. Vargens OMC, Progianti JM, Silveira ACF. O significado de desmedicalização da assistência ao parto no hospital: análise da concepção de enfermeiras obstétricas. Rev Esc Enferm USP [Internet]. 2008 Jun; [cited 2017 Jun 9]; 42(2):339-46. Available from: http://www.scielo.br/scielo.php?script=sci_arttext\&pid =S0080-62342008000200018. DOI: http://dx.doi.org/10.1590/S008062342008000200018

6. Vargens OMC, Silva ACV, Progianti JM. Non-invasive nursing technologies for pain relief during childbirth - The Brazilian nurse midwive's view. Midwifery [Internet]. 2013 Nov; [cited 2017 Sep 9]; 29(11):e99-e106. Available from: https://www.ncbi.nlm.nih.gov/pubmed/23481340

7. World Health Organization (WHO).WHO recommendations: intrapartum care for a positive childbirth experience. Geneva: WHO; 2018. Available from: http://www.who.int/reproductivehealth/publications/intrapartumcare-guidelines/en

8. Ministério da Saúde (BR). Diretrizes nacionais de assistência ao parto normal. Brasília (DF): Ministério da Saúde; 2017. Available from: http:// bvsms.saude.gov.br/bvs/publicacoes/diretrizes_nacionais_assistencia_ parto_normal.pdf

9. Vargens OMC, Reis CSC, Nogueira MFH, Prata JA, Silva CM, Progianti JM. Tecnologias não-invasivas de cuidado de enfermagem obstétrica: repercussões sobre a vitalidade do recém-nascido. Rev Enferm UERJ [Internet]. 2017; [cited 2018 Apr 10]; 25:e21717. Available from http://www.e-publicacoes.uerj.br/index.php/enfermagemuerj/article/ view/21717/22670. DOI: http://dx.doi.org/10.12957/reuerj.2017.21717

10. Brüggemann OM, Oliveira ME, Martins HEL, Alves MC, Gayeski ME. A inserção do acompanhante de parto nos serviços públicos de saúde de Santa Catarina, Brasil. Esc Anna Nery [Internet]. 2013 Jul/Sep; [cited 2017 Oct 28]; 17(3):432-38. Available from: http://www.scielo.br/pdf/ean/v17n3/ en_1414-8145-ean-17-03-0432.pdf. DOI: http://dx.doi.org/10.1590/ S1414-81452013000300005

11. Hanum AP, Mattos DV, Matão MEL, Martins CA. Estratégias não farmacológicas para o alívio da dor no trabalho de parto: efetividade sob a ótica da parturiente. Rev Enferm UFPE On Line (Recife) [Internet]. 2017 Aug; [cited 2017 Dec 10]; 11(Supl. 8):3303-9. Available from: https://periodicos.ufpe.br/revistas/revistaenfermagem/article/ viewFile/110197/22089.DOI: http://www.dx.doi.org/10.5205/reuol.1113599435-1-ED.1108sup201715

12. Mafetoni RR, Shimo AKK. Métodos não farmacológicos para alívio da dor no trabalho de parto: revisão integrativa. REME [Internet]. 2014 Apr/ Jun; [cited 2017 Dec 10]; 18(2):505-12. Available from: http://www.reme. org.br/artigo/detalhes/942. DOI: http://www.dx.doi.org/10.5935/14152762.20140037

13. Gomes ARM, Pontes DS, Pereira CCA, Brasil AOM, Moraes LCA Assistência de enfermagem obstétrica na humanização do parto normal. Rev Recienc [Internet]. 2014; [cited 2017 Oct 28]; 4(11):23-7. Available from: http://www.recien.com.br/index.php/Recien/article/view/73/137. DOI: http://dx.doi.org/10.24276/rrecien2358-3088.2014.4.11.23-27

14. Bardin L. Análise de conteúdo. 7a ed. Portugal: Loyola; 2010.

15. Ministério da Saúde (BR). Conselho Nacional de Saúde. Comissão Nacional de Ética em Pesquisa. Resolução № 466, de 13 de junho de 2012. Aprova as diretrizes e normas regulamentadoras de pesquisa envolvendo seres humanos. Brasília (DF): Ministério da Saúde; 2012 [cited 2016 Apr 20]. Available from: http://bvsms.saude.gov.br/bvs/ saudelegis/cns/2013/res0466_12_12_2012.html

16. Merhy EE, Feuerwerker LCM. Novo olhar sobre as tecnologias de saúde: uma necessidade contemporânea. In: Mandarino ACS, Gomberg E, orgs Leituras de novas tecnologias e saúde. São Cristóvão: Editora UFS;2009 p. 29-74.

17. Merhy EE. Saúde: cartografia do trabalho vivo em ato. São Paulo: Hucitec 2002.

18. Koerich MS, Backes DS, Scortegagna HM, Walt ML, Veronese A, Zeferino MT, et al. Tecnologias de cuidado em saúde e enfermagem e suas perspectivas filosóficas. Texto Contexto Enferm (Florianópolis) [Internet] 2006; [cited 2017 Oct 28]; 15(no.espe):178-85. Available from: http://www. scielo.br/pdf/tce/v15nspe/v15nspea22. DOI: http://dx.doi.org/10.1590/ S0104-07072006000500022 
19. Rocha PK, Prado ML, Wal ML, Carraro TL. Cuidado e tecnologia: aproximações através do modelo de cuidado. Rev Bras Enferm [Internet]. $2008 \mathrm{Jan} / \mathrm{Feb}$; [cited 2017 Oct 28]; 61(1):113-6. Available from: http://www.scielo.br/pdf/reben/v61n1/18.pdf. DOI: http://dx.doi. org/10.1590/S0034-71672008000100018

20. Sá Neto JA, Rodrigues BMD. Tecnologia como fundamento do cuidar em neonatologia. Texto Contexto Enferm [Internet]. 2010 Apr/Jun; [cited 2017 Oct 28]; 19(2):372-7. Available from: http://www.scielo.br/pdf/tce/ v19n2/20. http://dx.doi.org/10.1590/S0104-07072010000200020

21. Nietsche EA, Lima MGR, Rodrigues MGS, Teixeira JA, Oliveira BNB, Motta CA, et al. Tecnologias inovadoras do cuidado de enfermagem. Rev Enferm UFSM [Internet]. 2012 Jan/Abr; [cited 2017 Oct 28]; 2(1):182-9. Available from: https://periodicos.ufsm.br/reufsm/article/ view/3591/3144. DOI: http://dx.doi.org/10.5902/217976923591

22. Berardinelli LMM, Guedes NAC, Ramos JP, Silva MGN. Tecnologia educacional como estratégia de empoderamento de pessoas com enfermidades crônicas. Rev Enferm UERJ. [Internet]. 2014 Sep/Oct; [cited 2017 Oct 28]; 22(5):603-9. Available from: http://www.facenf.uerj. $\mathrm{br} / \mathrm{v} 22 \mathrm{n} 5 / \mathrm{v} 22 \mathrm{n} 5 \mathrm{a} 04 . \mathrm{pdf}$

23. Torres JA, Santos I, Vargens OMC. Construindo uma concepção de tecnologia de cuidado de enfermagem obstétrica: estudo sóciopoético. Texto Contexto Enferm [Internet]. 2008; [cited 2017 Sep 15]; 17(4):65664. Available from: http://www.scielo.br/scielo.php?pid=S010407072008000400005\&script=sci_abstract\&tlng=pt. DOI: http://dx.doi. org/10.1590/S0104-07072008000400005

24. Schwonke CRGB, Lunardi Filho WD, Lunardi VL, Santos SSC, Barlem ELD. Perspectivas filosóficas do uso da tecnologia no cuidado de enfermagem na terapia intensiva. Rev Bras Enferm [Internet]. 2011 Jan/Feb; [cited 2017 Oct 28]; 64(1):189-92. Available from: http://www. scielo.br/pdf/reben/v64n1/v64n1a28.pdf. DOI: http://dx.doi.org/10.1590/ S0034-71672011000100028

25. Silva DC, Alvim NAT, Figueiredo PA. Tecnologias leves em saúde e sua relação com o cuidado de enfermagem hospitalar. Esc Anna Nery Rev Enfem [Internet]. 2008 Jun; [cited 2017 Oct 28]; 12(2):291-8. Available from: http://www.scielo.br/pdf/ean/v12n2/v12n2a14. DOI: http://dx.doi. org/10.1590/S1414-81452008000200014

26. Teixeira E. Desenvolvimento de tecnologias cuidativo-educacionais. Porto Alegre: Moriá; 2017.

27. Santos FPA, Nery AA, Matumoto S. A produção do cuidado a usuários com hipertensão arterial e as tecnologias em saúde. Rev Esc Enferm USP [Internet]. 2013; [cited 2017 Oct 28]; 47(1):107-14. Available from: http://www.scielo.br/pdf/reeusp/v47n1/a14v47n1.pdf.DOI: http://dx.doi. org/10.1590/S0080-62342013000100014

28. Silva RC, Ferreira MA. Tecnologia no cuidado de enfermagem: uma análise a partir do marco conceitual da Enfermagem Fundamental. Rev Bras Enferm [Internet]. 2014 Jan/Feb; [cited 2017 Oct 28]; 67(1):1118. Available from: http://www.scielo.br/pdf/reben/v67n1/0034-7167reben-67-01-0111.pdf

29. Franco TB, Merhy EE. Cartografias do trabalho e cuidado em saúde. Rev Tempus Actas Saúde Coletiva (Brasília). [Internet]. 2012; [cited 2017 Oct 28]; 6(2):151-63. Available from: http://www.tempusactas.unb.br/index. php/tempus/article/view/1120/1034. DOI: http://dx.doi.org/10.18569/ tempus.v6i2.1120

30. Nietsche EA, Backes VMS, Colomé CLM, Ceratti RN, Ferraz F. Tecnologias educacionais, assistenciais e gerenciais: uma reflexão a partir da concepção dos docentes de enfermagem. Rev Lat Am Enferm [Internet]. 2005 May/Jun [cited 2017 Nov 10]; 13(3):344-53. Available from: http://www.scielo.br/pdf/rlae/v13n3/v13n3a09.pdf. DOI: http:// dx.doi.org/10.1590/S0104-11692005000300009
31. Melo MN, Amorim TV, Salimena AMO, Melo MCSC, Souza IEO. Cuidado hospital de mulheres que vivenciaram a gestação de alto risco: contribuições para a enfermagem. Rev Enferm UFPE On Line (Recife) [Internet]. 2016 Nov; [cited 2018 Dec 13]; 10(11):3911-7. Available from: https://periodicos.ufpe.br/revistas/revistaenfermagem/ article/viewFile/11472/13316. DOI: 10.5205/reuol.9881-87554-1EDSM1011201612

32. Errico LSP, Bicalho PG, Oliveira TCFL, Martins EF. O trabalho do enfermeiro no pré-natal de alto risco sob a ótica das necessidades humanas básicas. Rev Bras Enferm. [Internet]. 2018; [cited 2018 Dec 13]; 71(Suppl.3):1257-64. Available from: http://www.scielo.br/scielo. php?script=sci_arttext\&pid=S0034-71672018000901257\&lng=en\&t ng=en. DOI: http://dx.doi.org/10.1590/0034-7167-2017-0328

33. Amorim TV, Souza IEO, Moura MAV, Queiroz ABA, Salimena AMO. Perspectivas de los cuidados de enfermería en el embarazo de alto riesgo: revisión integradora. Enferm Global. [Internet]. 2017 Apr [cited 2018 Dec 13]; 16(2):500-14. Available from: http://revistas. um.es/eglobal/article/view/238861. DOI: https://doi.org/10.6018/ eglobal.16.2.238861

34. Osório SMB, Silva Júnior LG, Nicolau AIO. Avaliação da efetividade de métodos não farmacológicos no alívio da dor do parto. Rev Rene [Internet]. 2014 Jan/Feb; [cited 2017 Oct 28]; 15(1):174-84. Available from: http://periodicos.ufc.br/rene/article/view/3112/2386. http://dx.doi org/10.15253/rev\%20rene.v15i1.3112

35. Gouvêa AN, Lopes ALF, Rossi CS, Araújo LM, Pinto ELG. Métodos não farmacológicos para o alívio da dor durante o trabalho de parto. In: Trajano AJB, Monteiro DLM, Jesús NR, orgs. Hospital Universitário Pedro Ernesto - Série Rotinas Hospitalares: Obstetrícia. 1a ed. Rio de Janeiro: Triunfal; 2015

36. Oliveira LMN, Cruz AGC. A Utilização da Bola Suíça na promoção do parto humanizado. Rev Bras Ciênc Saúde [Internet]. 2014; [cited 2017 Oct 28]; 18(2):175-80. Available from: http://www.periodicos. ufpb.br/ojs/index.php/rbcs/article/view/16698/12924. DOI: 10.4034/ RBCS.2014.18.02.13

37. Silva DAO, Ramos MG, Jordão VRV, Silva RAR, Carvalho JBL, Costa MMN. Uso de métodos não farmacológicos para o alívio da dor durante o trabalho de parto normal: revisão integrativa. J Nurs UEFP (Recife) [Internet]. 2013 May; [cited 2017 Oct 28]; 7(no.espe):4161-70. Available from: https://periodicos.ufpe.br/revistas/revistaenfermagem/ article/view/11645/13745. DOI: https://doi.org/10.5205/1981-8963v7i5a11645p4161-4170-2013

38. Santana LS, Gallo RBS, Ferreira CHJ, Quintana SM, Marcolin AC. Efeito do banho de chuveiro no alívio da dor em parturientes na fase ativa do trabalho de parto. Rev Dor (São Paulo) [Internet]. 2013 Apr/ Jun; [cited 2017 Oct 28]; 14(2):111-3. Available from: http://www. scielo.br/pdf/rdor/v14n2/07.pdf. DOI: http://dx.doi.org/10.1590/S180600132013000200007

39. Martins AA, Franco TB, Merhy EE, Feuerwerker LCM. A produção do cuidado no programa de atenção domiciliar de uma cooperativa médica. Physis [Internet]. 2009; [cited 2018 Dec 15]; 19(2):457-74. Available from: http://www.scielo.br/pdf/physis/v19n2/v19n2a12.pdf 